\title{
Die gesag waarmee Jesus geleer het volgens Matteus 7:29
}

\begin{abstract}
Author:
Francois P. Viljoen ${ }^{1}$

Affiliation:

${ }^{1}$ School for Biblical Science and Ancient Languages, North-West University,

South Africa

Correspondence to:

Francois Viljoen

Email:

viljoen.francois@nwu.ac.za

Postal address:

Private Bag X6001,

Potchefstroom 2520,

South Africa

Dates:

Received: 16 May 2011

Accepted: 24 Oct. 2011

Published: 27 Feb. 2012

How to cite this article: Viljoen, F.P., 2012, 'Die gesag waarmee Jesus geleer het volgens Matteus 7:29',

HTS Teologiese Studies/ Theological Studies 68(1), Art. \#1086, 7 pages. http:// dx.doi.org/10.4102/hts. v68i1.1086
\end{abstract}

C) 2012. The Authors. Licensee: AOSIS OpenJournals. This work is licensed under the Creative Commons Attribution License.
The authority with which Jesus taught according to Matthew 7:29. This article focuses on Matthew's claim as conclusion to the Sermon to the Mount that Jesus preached with unparalleled authority. To grasp the meaning and intention of this claim in Matthew 7:29, this statement is read as part of the development of the theme of Jesus' authority within the Matthean gospel. The authority of Jesus is interpreted in relation with the authority of powerful imperial and Jewish figures of his time and the development of the concept of $\dot{\xi} \xi o v \sigma i \alpha$ [authority] in the first gospel. It is argued that by this claim Matthew intends to confirm the conviction of his community that Jesus is the Messiah and authoritative interpreter of the Law. Matthew argues that God's kingdom has come despite opposition from the synagogue and its leaders, and of the physical dominance of imperial powers. As the church enjoys a privileged position in this kingdom, it has credibility and the authority to execute the commandments of Jesus.

\section{Inleiding}

Die Matteus-evangelie is geskryf om Christenskap te verdedig en te bevestig. Lesers word verseker van die geloofwaardigheid van hulle geloof. Om hierdie versekering te bied, beklemtoon die outeur 'n aantal aspekte. Een belangrike aspek is die gesag van Jesus soos wat dit uit sy onderrig blyk (Matt 7:29).

Ten einde die gesag van Jesus en sy prediking te begryp, is dit nodig om die tema van gesag binne die konteks van die Matteus-evangelie te lees. Met die ontwikkeling van sy verhaal, demonstreer Matteus die gesag van Jesus op 'n verskeidenheid van maniere.

Matteus beskryf Jesus se gesag deur dit met dié van ander gesagsfigure in die tyd van Jesus te kontrasteer, naamlik van die Romeinse imperiale ryk en van sinagogale leiers. Op drie plekke maak Matteus ook daarop aanspraak dat Jesus vir God op aarde verteenwoordig: 'hulle sal Hom Immanuel noem. Die naam beteken God by ons' ( $\mu \varepsilon \theta$ ’ n் $\mu \hat{v} \nu$ ò $\theta \varepsilon o ́ s)$ (Matt 1:23); 'waar daar twee of drie in my Naam saam is, daar is Ek by hulle' (Matt 18:20); en 'Ek is by julle al die dae tot die voleinding van die wêreld' (Matt 28:20). Hierdie aankondigings staan teenoor die aansprake van die Romeine dat die keiser as agent van Jupiter, dié god verteenwoordig (proximus ille deus) (Publius Papinius Statius, Silvae 5.2.170). Jesus is die geliefde Seun van God (Matt 3:17 en 17:5). Hierbenewens moet Matteus se aansprake oor die gesag van Jesus ook gelees word teen die agtergrond van die konsep van auctoritas wat die basis van die Romeinse Imperium gevorm het.

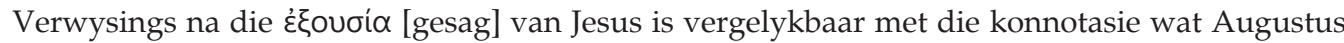
aan die begrip auctoritas geheg het. Volgens Matteus konstateer Jesus ook teenoor die Joodse leiers dat Iemand groter as die tempel hier is (Matt 12:6), asook Iemand groter as Jona (Matt 12:41), en Iemand groter as Salomo (Matt 12:42).

Matteus verwys herhaaldelik na die gesag ( $\dot{\xi} \xi o v \sigma i ́ \alpha)$ van Jesus. Hy besit unieke gesag, en Hy verleën dit aan sy dissipels (en per implikasie aan die kerk). Hierteenoor bevraagteken Jesus se opponente sy gesag en kritiseer hulle Hom vir sy aansprake. Die Evangelie sluit klimakties af met die uitspraak van Jesus dat Hy alle gesag in die hemel en op aarde besit. Op grond daarvan gee Hy aan sy dissipels opdrag om dit wat Hy gesagvol geleer het, aan alle nasies te gaan verkondig.

In hierdie artikel word op die gesag van Jesus se prediking gefokus (Matt 7:29). Om die konteks van hierdie vers te verstaan, word die vraagstuk van Jesus se gesag binne die ontplooiing van die tema van Jesus se gesag in die Evangelie geplaas. Die ondersoek begin deur die kontrastering van Jesus se gesag met dié van ander magsfigure van sy tyd. Daarna volg 'n verduideliking van die

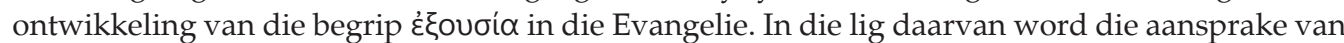

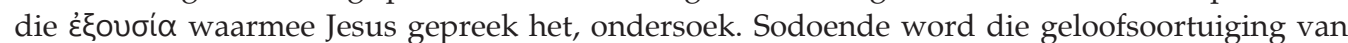
die Matteusgemeenskap dat Jesus die ware Messias is, bevestig. Te midde van teenkanting van die sinagoge en sy leiers, het die kerk bestaansreg en gesag om die opdragte van Jesus uit te voer. 


\section{Gesag in die Matteusevangelie}

Matteus ontplooi die tema van Jesus se gesag in kontras met die mag en gesag van Romeinse imperiale figure en dié van Joodse leiers. Hy toon met eienskappe, wat tipies aan die keiser toegedig word, aan dat Jesus met besondere gesag die Bergrede gelewer het en hierdie gesag met sy dade bevestig het.

\section{Gesag van Jesus teenoor die imperiale figure}

Matteus berig van die gesag van Jesus teenoor dié van die imperiale Romeinse magte by wyse van 'n kontra-narratief (vgl. Carter 2000:4). Hy verwys na Herodes die Grote (Matt 2) en Herodes Antipas (Matt 14:1-12) as Romeinse bondgenote. Op 'n indirekte wyse word daar in terme van die betaling van belasting na die keiser verwys (Matt 17:24-27 en 22: 15-22), terwyl Pilatus regstreeks as persoon voorgestel word (Matt 27). Op 'n subtiele manier vertel Matteus dat die gesag van hierdie maghebbers voor die gesag van die skynbaar magtelose Jesus kwyn en swig.

Aansprake deur die Romeine dat dit die wil van die gode was dat hulle die wêreld regeer het, was grondliggend tot die Romeinse imperiale ideologie (vgl. Virgilius, Aeneas, 1.278-279; Cicero, De Officiis, 2.26-27). Die Romeinse regeerders het as agente van die gode, die guns van Jupiter en ander gode geniet (Carter 2001:34). Hierteenoor verkondig Matteus 'n alternatiewe koninkryk ( $\left.\beta \alpha \sigma \iota \lambda \varepsilon^{\prime} \alpha\right)$ wat met die koms van Jesus aangebreek het (France 2008a:116). Jesus se gesag

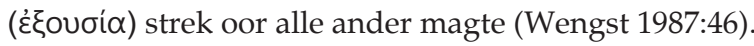

Matteus plaas die lewe van Jesus en sy volgelinge binne die konteks van die imperiale magte. Herodes die Grote, Herodes Antipas en Pilatus word voorgestel met titels en oorweldigende gesag. Oppervlakkig beskou lyk dit asof Jesus en sy volgelinge weerloos voor hulle magsmisbruik staan, maar op 'n subtiele en ironiese manier beskryf Matteus hoe hulle patetiese figure word as God ingryp. Matteus leer dat iets veel groter as wat die natuurlike oog kan waarneem, besig is om te gebeur (Weaver 1996:180).

Volgens Matteus 2 is Jesus as die weerlose kindjie oënskynlik aan die gruwelike magsmisbruik van Herodes die Grote uitgelewer. Die onderliggende argument is egter dat Herodes nie werklik die koning van die Jode is nie en dat hy nie finale gesag dra nie. Op 'n ironiese manier beskryf Matteus dat Jesus, die pasgebore kindjie, die eintlike Koning van die Jode is. Op die ou end is Herodes en diegene wat die kindjie wou doodmaak self dood, terwyl Jesus lewe. Na die dood van Herodes gaan Josef hom met Maria en die kindjie in Nasaret vestig. Die eintlike gesag behoort aan die skynbaar weerlose kindjie en nie aan die skrikaanjaende despoot nie (vgl. Patte 1987:37; Senior 1998:50). Later in die narratief word Herodes Antipas ewe ironies voorgestel (Matt 14). Tydens sy joviale fuifparty word Herodes Antipas beskryf as 'n persoon met uitermatige invloed en mag. Sy statuur verkrummel egter, aangesien hy Jesus verwar het met Johannes vir wie hy vroeër laat onthoof het. Terwyl hy van mening was dat hy met Johannes se onthoofding van sy teenstander en sy kritiek ontslae geraak het, was hy vreesbevange toe hy gedink het dat Jesus Johannes was wat uit die dood opgestaan het ${ }^{1}$. Hy was oortuig dat Johannes toe selfs groter krag gehad het as die Johannes wat hy laat onthoof het. Wanneer Jesus voor Pilatus verskyn, slaan Pilatus ook uiteindelik 'n patetiese figuur. Pilatus word as goewerneur ( $\dot{\eta} \gamma \varepsilon \mu \omega \dot{v}$ ) voorgestel. Sy gesag word beklemtoon deur die sewevoudige gebruik van dié magstitel in die toneel (Matt 27:2, 11 [twee keer], 14, 15, $21 ; 28: 14)$. Hoewel hy volgens die titel op daardie stadium die magtigste persoon in Palestina was, staan hy magteloos voor die skreeuende skare wat Jesus oorgelewer wou hê (Matt 27). Die ironie bereik sy klimaks wanneer die Joodse leiers Pilatus om die bos lei oor die verdwene liggaam van Jesus. Matteus vertel egter dat die skynbaar weerlose Jesus die dood oorwin en alle gesag in hemel en op aarde ontvang het (Matt 28).

\section{Gesag van Jesus en die kerk onderskeidelik teenoor die Joodse leiers en die sinagoge}

Benewens die konflik van Romeinse mag met die gesag van Jesus, vertel Matteus ook van die groeiende weerstand van die Joodse gemeenskap teenoor Jesus en sy dissipels. Hierdie weerstand lei tot ' $n$ afskeiding van die Matteaanse gemeenskap vanaf die sinagoge en die oorwinning van Jesus teenoor sy teenstanders (Overman 1990:35). Hierdie stryd sou ook lei tot spanning wat gedurende die eerste eeu tussen die Jesus-volgelinge en ander Joodse gemeenskappe ontstaan het (bv. Hummel 1966:55; Keener 1999:46; Repschinski 2000:63; Saldarini 1994:46) en in die Matteus-teks weerspieël word. Radford Reuther (1974:30) beskryf dit as 'n 'family conflict' wat verband hou met 'rival claims to exclusive truth within the same religious symbol system'. Hummel (1966:55) praat selfs van 'n wedywering tussen 'feindliche Brüder' oor die waarheid. Strydende Joodse sektes en verskeie apokaliptiese groepe het om selfhandhawing meegeding (Overman 1990:6). Die gevolg is dat ook die sogenaamde 'Jesus-beweging' betrek is by die stryd tussen die Joodse godsdienstige groepe (Luz 2001:255; Saldarini 1991:49). Argumente oor gesag en waarheid het daarom ' $n$ wesenlike rol in die selfdefiniëring van die Christelike gemeenskap gespeel.

In teenstelling met die sinagoge, noem Matteus hierdie nuwe

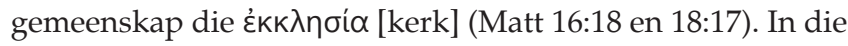
LXX word die woord algemeen gebruik vir die vertaling van die Hebreeuse woord qahal, die vergadering van die volk van

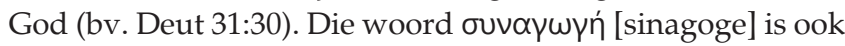
dikwels gebruik as vertaling van qahal (Keener 1999:428). Deur sy gebruik van hierdie gevoelsbelaaide konsep uit die

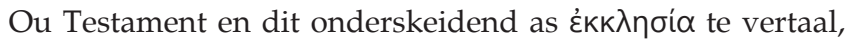
wil Matteus klaarblyklik aantoon dat die kerk die rol van die Ou-Testamentiese volk van God oorgeneem het. Hy onderskei hierdie groep van die sinagoge en sy leiers (Luz 2001:358). Hierdie beskrywing van die kerk werp 'n skadu oor die gesag van die sinagoge. Die skerpste polemiek staan in hoofstuk 23 met sy sewe ellende-spreuke wat afsluit met die strafwaardigheid van 'hierdie geslag'.

1.Die idee van ' $n$ geestelike of fisiese terugkeer van ' $n$ invloedryke persoon wie se invloed deur ' $n$ gewelddadige dood beëindig is, was deel van die algemene bygeloof in die antieke tyd (France 2007:553). 
Die Fariseërs en skrifgeleerdes het met die kerk meegeding om die gesag oor en invloed op die populêre gemeenskap (Saldarini 1994:44). Matteus laat blyk dat die Fariseërs en skrifgeleerdes nie bevoeg was om die leiers en verteenwoordigers van die ware godsdienstige gemeenskap te wees nie (Repschinski 2000:63). Matteus verskerp Markus se verwysings na die Joodse leiers se rol in die teenstand en moord op Jesus. Uniek aan Matteus is sy beskrywing van die skrifgeleerdes en Fariseërs as 'blinde leiers' en 'blinde dwase' (Matt 23:16, 17, 19, 24, 26; 15:14). Matteus identifiseer die Joodse leiers as Jesus se opponente, terwyl die skares as toeskouers van hierdie konflik beskryf word. Jesus tree onteenseglik elke keer as oorwinnaar uit die stryd. Die kerk verteenwoordig die gesag van Jesus. Volgens Repschinski (2000):

Matthew intends the audience of the controversy stories to reflect a group that turns from the fraudulent leadership of the opponents of Jesus towards an acknowledgement of the Matthean community as the rightful leaders of Israel. (p. 329)

Die uitdrukking 'the parting of the ways' soos deur Dunn (1980, 1991) gebruik en deur Stanton (1992:99-116) gepopulariseer is, kenmerk hierdie skeiding. Bornkamm (1963:40) verduidelik hoe die kerk hulle van die Judaïsme van die sinagoge afgeskei het: 'no longer ... the rabbinical teaching of the synagogue, but ... discipleship.'

Die Matteus-teks openbaar verset teen die gesag van die Joodse leiers en woordvoerders van die sinagoges (Viljoen 2007:700). Matteus 23:13 berig:

Ellende wag vir julle, skrifgeleerdes en Fariseërs, huigelaars! Julle sluit die deur van die koninkryk in die mense se gesig toe. Julle gaan self nie in nie, en julle verhinder dié wat wel wil ingaan.

Hierteenoor argumenteer Matteus dat die sleutels van die koninkryk van die hemele aan die leiers van die kerk toevertrou is (Matt 16:19² en 18:18 ${ }^{3}$ ).

Die gesag van die kerk is in Jesus geleë. Jesus beskik finaal oor die gesag, maar Hy delegeer dit op 'n bepaalde manier aan sy verteenwoordigers op aarde (Viljoen 2009:660).

\section{Gesag as tema in Matteus}

Gelees teen die agtergrond van magskonflik soos hierbo beskryf, word dit duidelik hoe die gesag ( $(\dot{\xi}$ ovoía) van Jesus ' $n$ belangrike tema in die Matteus-evangelie vorm. Matteus baseer sy Christologie op sy aanspraak dat Jesus as verteenwoordiger van die koninkryk ( $\beta \alpha \sigma i \lambda \varepsilon i \alpha)$ van God, met unieke en onvergelykbare gesag optree. Matteus beklemtoon dat Jesus met sy eie gesag optree, gebaseer op die ware identiteit van Jesus. Daarbenewens verleen Hy ook gesag aan sy dissipels.

Matteus verwys herhaaldelik na Jesus se gesag. Met betrekking tot Jesus se prediking verwys Matteus na die

2.Matteus 16:19: 'Ek sal aan jou die sleutels van die koninkryk van die hemel gee, en wat jy op die aarde toesluit, sal in die hemel toegesluit by; en wat jy op die aarde oopsluit, sal in die hemel oopgesluit bly.'

3.Matteus 18:18: 'Dit verseker Ek julle: Wat julle ook al op die aarde toesluit, sal in die hemel toegesluit bly; en wat julle ook al op die aarde oopsluit, sal in die heme oopgesluit bly.' skare se verbasing oor sy onderrig, want Hy het hulle

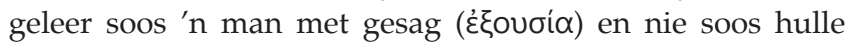
skrifgeleerdes nie (Matt 7:29). Matteus lê ook 'n verband tussen Jesus se optrede en sy gesag. Jesus het 'n verlamde man gesond gemaak en aangekondig dat sy sondes vergewe is. Hieroor was die skrifgeleerdes uiters ontsteld en is Jesus van godslastering beskuldig. Daarop het Jesus verklaar dat Hy as Seun van die mens gesag ( $\dot{\xi} \xi o v \sigma i ́ \alpha)$ het om op aarde sondes te vergewe (Matt 9:6). Die afloop van die gebeurtenis was dat die menigte mense met ontsag vervul is, omdat God soveel gesag ( $\left(\dot{\xi}\right.$ ou $\left.\boldsymbol{i}^{\alpha} \alpha\right)$ aan mense gegee het (Matt 9:8).

Jesus het ook gesag aan sy volgelinge verleën. Toe Jesus die

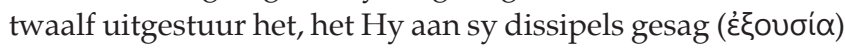
verleen om bose geeste uit te dryf en om elke soort siekte en kwaal gesond te maak (Matt 10:1). Per implikasie verleen Hy ook gesag aan die kerk van alle eeue, toe Hy sy dissipels opdrag gegee het om dissipels te maak van alle nasies (Matt 28:18).

Die priesterhoofde en familiehoofde het Jesus se aansprake op gesag ernstig bevraagteken en gekritiseer: 'Met watter gesag ( $(\dot{\xi} \xi 0 \cup \sigma i ́ \alpha)$ doen $\mathrm{u}$ hierdie dinge? En wie het $\mathrm{u}$ hierdie

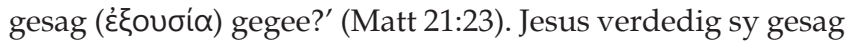
met 'n vraag oor die gesag waarmee Johannes die Doper opgetree het (Matt 21:24-27).

Die aansprake oor die gesag van Jesus bereik sy klimaks met

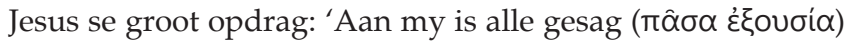
gegee in die hemel en op aarde' (Matt 28:18). Die hemel en aarde verwys na die hele skepping waaroor God soewerein deur Jesus beheer uitoefen. Jesus gee daarom aan sy dissipels opdrag om dissipels onder alle nasies te maak en hulle te doop en te leer om alles te onderhou wat Jesus hulle beveel het.

Hierdie klimaktiese verwysing na die gesag van Jesus sinspeel waarskynlik op die woorde in Daniël 7:14 (LXX):

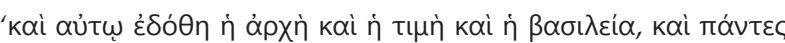

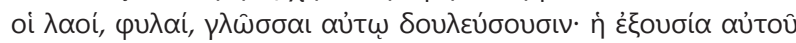

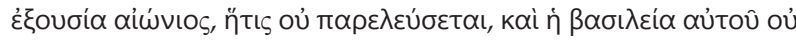

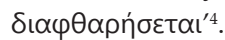

Matteus maak 'n Christologiese toepassing van die troonsbestyging van die Seun van die mens in Daniël (France 1989:314; Hendriksen 1973:998). Deur die loop van die Evangelie verwys Matteus telkens na die koningskap van Jesus. Tydens sy bediening op aarde het Hy met gesag opgetree. Volgens Matteus 11:17a verklaar Jesus dat die Vader alles aan Hom toevertrou het. Na sy opstanding volg sy troonsbestyging waardeur sy gesag oor alles en almal bevestig word. As Koning en Regter sal Hy weer kom om finaal te oordeel (Matt 25:31-46). Die universele gesag wat Jesus met sy troonsbestyging ontvang het, bied die grond vir die uitsending van sy dissipels met die nodige gesag wat Hy verleen. Wanneer sy dissipels (en die vroeë kerk) weerstand sou ervaar, kan hulle op Hom vertrou.

4.Daniël 7:14: 'Aan hom is die heerskappy en eer en koningskap gegee sodat al die volke, nasies en taalgroepe hom sou dien. Sy heerskappy is 'n ewige heerskappy, dit sal nie tot niet gaan nie, en sy koningskap sal nie ophou nie.' 
In die afsluiting van die Evangelie kom, deur die manier waarop Jesus voorgestel is, duidelik aan die lig waarvan die lesers deurlopend van bewus geraak het. Die verwysing na Jesus se gesag ( $(\xi \xi o v \sigma i \alpha)$ in die konkluderende formule van die Bergrede (Matt 7:29), speel 'n belangrike rol in antisipasie van die daaropvolgende verhaal waarin daar herhaaldelik en eksplisiet na die gesag van Jesus verwys word (Matt 9:6, $8 ; 10: 1 ; 21: 23-27)$. Met die slot van die Bergrede breek die strale van die mag en heerlikheid van die hemelse Here reeds deur (Luz 1989:456). Volgens die slot-episode bestyg die verrese Here die troon as die Seun van die mens. Hy word verhef bo die konflik en verwerping waarmee Hy op aarde gekonfronteer was.

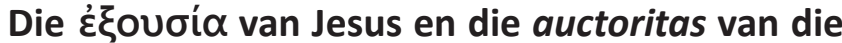 keiser}

Die manier waarop Matteus na die gesag van Jesus verwys, sluit aan by die Romeinse begrip auctoritas in teenstelling met potestas (vgl. Cicero, De Legibus, 3.31). Die begrip auctoritas het ' $\mathrm{n}$ wesenlike rol in die Romeinse Ryk gespeel. In teenstelling met potestas wat bloot na mag verwys het, dra auctoritas die betekenis van materiële, intellektuele en morele superioriteit en leierskap (Galinsky 1996:12). Auctoritas hou verband met die unieke insig en gesag van die keiser as auctor. Dit veronderstel ontsag en respek van onderdane oor wie die auctoritas uitgeoefen word. Dit is daarom nie 'n statiese begrip nie, maar iets wat toeneem (augere - van dieselfde stam afgelei) deur voortgaande woorde en optrede, waardeur die gesag en ware invloed van die auctor bevestig en geverifieer word. Matteus beskryf Herodes die Grote, Antipas en Pilatus as persone wat met (grootliks despotiese en immorele) potestas optree. Hier teenoor tree Jesus op grond van sy materiële, intellektuele en morele superioriteit en leierskap in die ware sin met auctoritas op.

Die gesag van die keiser is verder versterk deur die religieuse konnotasie wat aan die keiser geheg is. Die keiser het die eretitel van Caesar divi filius ontvang en het sodoende besondere intellektuele en morele gesag ontvang. Die salus rei publicae was van hierdie posisie van die keiser afhanklik. Eweneens stel Matteus Jesus as 'ò viòs toû $\theta \varepsilon$ coû' [die Seun van God] voor. Talle navorsers beskou dit as die grondliggende titel van Jesus in Matteus (France 1989:293; Kingsbury 1976:591; Senior 1998:54). Matteus stel Jesus voor as die maagdelik gebore Seun wat op 'n unieke manier vir God onder sy mense verteenwoordig (Matt 1:23). Met sowel die doop as verheerliking verklaar 'n stem uit die hemel dat Jesus die geliefde seun van God is: 'Oûtós દ̇otıv ò viòs

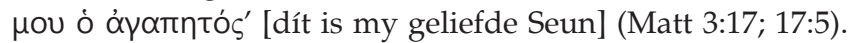
Jesus word selfs deur die demone as Seun van God herken (Matt 8:29), en Hy demonstreer sy gesag oor die natuur (Matt 14:33). Die hoëpriester verwys as sodanig na Jesus en Hy aanvaar dit so (Matt 26:63). Die centurion herken Hom ook as die Seun van God (Matt 27:54). In die gelykenis van die huurlinge (Matt 21:37) verwys die Matteaanse Jesus op 'n indirekte manier na Homself as die Seun van God. Teenoor sy dissipels identifiseer Hy Homself regstreeks as die Seun van God met verwysing na die koms van die Seun van die mens (Matt 24:36).
Galinsky (1996) verwys na die transformerende leierskap van die keiser as divi filius wat deur sy intellektuele en morele gesag die salus rei publicae sou verseker. Die optrede van so 'n keiser hou 'n verskeidenheid aktiwiteite in, naamlik:

elevating, mobilizing, inspiring, exalting, uplifting, preaching, exhorting, evangelizing ... transforming leadership ultimately becomes moral in the sense that it raises the level of human conduct and ethical aspiration of both leader and led, and thus it has a transforming effect on both. (p. 19)

Dit is onmiskenbaar die beeld wat Matteus van Jesus en sy onderrig voorhou.

\section{Jesus gee onderrig met ongekende gesag}

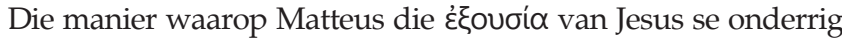
beskryf, stem grootliks ooreen met die aansprake oor die auctoritas van redevoering van die keiser. Dit blyk uit die feit dat Matteus die Bergrede deel maak van 'n dramatiese ontwikkeling en op 'n treffende manier afsluit.

\section{Die Bergrede as deel van 'n dramatiese ontwikkeling}

Matteus het pas met die dramatiese momentum van sy vertelling begin voor hy skynbaar die spanningslyn met 'n monoloog van Jesus, wat oor drie hoofstukke (Matt 5-7) strek, onderbreek. By nadere ondersoek blyk dit egter dat Matteus die Bergrede op 'n strategiese plek in die ontwikkeling van sy argument plaas. Die Bergrede is die eerste en langste van Jesus se vyf redes wat Matteus weergee. Hierdie rede vorm deel van Matteus se dramatiese ontwikkeling (France 1989:164). Die rede dra daartoe by om vir die leser 'n beter begrip te gee van wie Jesus is en wat verder van Hom verwag kan word.

In die Bergrede handel Jesus oor die unieke lewe van dissipels in die koninkryk van die hemel. Hierdie rede volg op die roeping van sy eerste dissipels. Die roeping vind plaas voor groot skares ${ }^{5}$ te midde van wie hulle van toe af onderskeidend en waardig hulle roeping moes optree (Matt 4:18-25). In latere hoofstukke word daar telkens verwys na die eise wat die roeping aan die dissipels sou stel (bv. Matt 8:18-22; 9:9-17; 9:35-10:4). In die Bergrede verduidelik Jesus die hoë vlak van etiese optrede wat van hulle verwag word. Hierdie rede sou 'n transformerende effek op sy dissipels uitoefen. Hiermee mobiliseer en inspireer Jesus sy dissipels tot optrede wat hulle van die ander mense sou onderskei.

Hierbenewens dien die rede daartoe om die lesers voor te berei op Jesus se wonderwerke wat in die komende hoofstukke (Matt 8-9) volg. Die wonderwerke demonstreer Jesus se gesag en dat die koninkryk aangebreek het. Matteus lig Jesus se gesag toe deur na sy unieke prediking te verwys. Daarop word sy gesag getoon deur sy wonderwerke wat volg.

5.Met die inleidende woorde tot die Bergrede word daar op hierdie onderskeiding tussen die dissipels en die groot skare gesinspeel (Matt 5:1). 
Met die Bergrede raak die leser bewus van dieperliggende vraagstukke wat in spel is. Terwyl die rede grotendeels oor dissipelskap handel, is dit duidelik dat Matteus ' $n$ belangrike Christologiese motief daarmee het. Davies (1963:435) merk op 'The Sermon on the Mount compels us, in the first place, to ask who he is who utters these words: they are themselves kerygmatic' en Banks (1974) skryf oor die Jesus se interpretasie van die wet in die Bergrede:

It is not so much Jesus' stance towards the Law that he (Matthew) is concerned to depict: it is how the Law stands with regard to him, as the one who brings it to fulfilment and to whom all attention must now be directed. (p. 226)

In die lig hiervan is dit duidelik waarom die Bergrede afsluit met die verbasing van die skare oor die gesag van Jesus. Wanneer die verhaal dan verder ontplooi met 'n beskrywing van die wonderdade van Jesus, volg dit logies op die impak wat sy prediking reeds op die skare gemaak het. Sodoende lei Matteus sy lesers om besondere respek te ontwikkel vir die lewe en onderrig van Jesus (Van Bruggen 1990:81).

Matteus beklemtoon die impak van die Jesus se prediking deur dit in die vorm van 'n monoloog aan te bied. Daar is geen dialoog nie, geen vrae word gestel nie en daar is geen mondelinge reaksie nie. 'Jesus' words are ringed in silence' (Davies \& Allison 2004:725). Alle aandag word op Jesus gefokus. Matteus bied sy prediking as uniek en gesagvol aan. Jesus se woorde dwing respek en stilswye af.

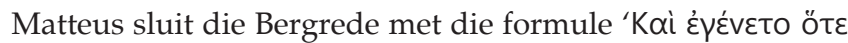

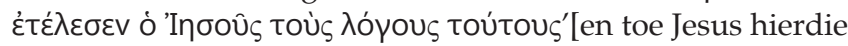
woorde geëindig het] af. Hierdie formule word verbatim in Matteus 11:1; 13:53; 19:1 en 26:1 herhaal. Die formule gebruik Ou-Testamentiese taal (LXX Num 16:31; Jos 4:11; 1 Sam 13:10; Jer. 26:8). Matteus gebruik die woorde om telkens na die vyf groot redes van Jesus te verwys, die impak van sy woorde te bevestig en 'n oorgang na die daaropvolgende episodes te bewerkstellig. 'The formula is clearly important as a signpost to the development of Matthew's theme' (France 2008b:154). Soos wat die auctoritas van die keiser in sy redes gedemonstreer is (Galinsky 1996:19), stel Matteus hoe Jesus telkens met sy redes gesag by sy hoorders afgedwing het.

\section{Vorlage en aanpassings}

Die veelseggende formule waarmee Matteus die eerste rede $\left(\right.$ Bergrede $^{6}$ ) van Jesus konkludeer, toon aanpassing teenoor die Vorlage daarvan. Matteus se slotformule lui:

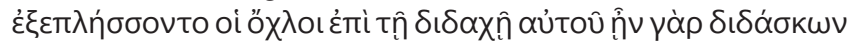

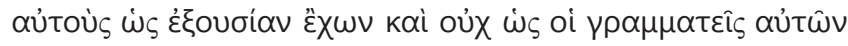
[Toe Jesus klaar gepraat het, was die skare verbaas oor sy onderrig, want Hy het hulle geleer soos 'n man met gesag en nie soos hulle skrifgeleerdes nie] (Matt 7:28-29). Met uitsondering van die unieke konkluderende woord: 'Toe Jesus klaar gepraat het' (Matt 7:28a), kom die res van die vers

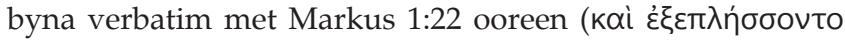

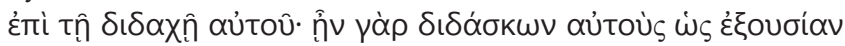

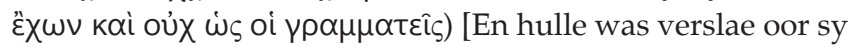

leer, want Hy het hulle geleer soos een wat gesag het en nie soos die skrifgeleerdes nie]. In Lukas 4:32 word daar van 'n soortgelyke reaksie van mense wat gereeld na Jesus geluister

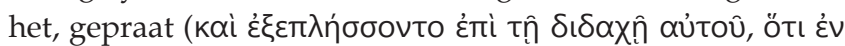

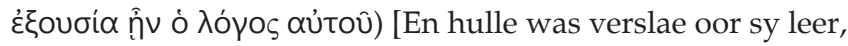
wat sy woord was met gesag]. Die woorde in Markus vorm waarskynlik die Vorlage van die opmerkings in Lukas 4:32 en Matteus 7:28-297. In Markus en Lukas kom hierdie stelling vroeg in die narratief voor sonder dat enige spesifieke gedeelte van Jesus se onderrig weergegee word (hoewel dit in Lukas na die optrede van Jesus in die sinagoge by Nasaret volg). Markus verwys na die reaksie van die skare op Jesus se onderrig in die sinagoge in Kapernaum, sonder om enige besonderhede te bied oor wat Jesus geleer het. Matteus koppel die woorde regstreeks aan Jesus se eerste groot rede en konstateer daardeur die tipiese impak wat die rede van die Seun van God wat met gesag optree, op die skare behoort te hê. Hy lê sodoende die basis van wat 'n mens van die onderrig van Jesus kan verwag.

Matteus maak aanpassings in sy formulering van die

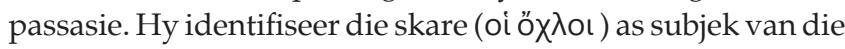
verbasing en verwys na 'hulle' skrifgeleerdes (oi $p \rho \alpha \mu \mu \alpha \tau \varepsilon \hat{\varsigma} \varsigma$

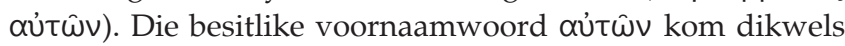
in die Matteus-evangelie voor, hoofsaaklik in verband met sinagoges (Matt 4:23; 9:35; 10:17; 12:9; 13:54, ens.), maar ook ten opsigte van stede (Matt 11:1). Met hierdie voornaamwoord distansieer Matteus sowel vir Jesus en sy volgelinge, as homself en die Matteusgemeenskap van die Judaïsme(s) van daardie tyd (Cousland 2002:70). Daarbenewens word die positiewe impak van Jesus se prediking op die skares regstreeks met dié van die skrifgeleerdes gekontrasteer.

\section{Jesus is anders as 'hulle' skrifgeleerdes}

Matteus impliseer dat Jesus mededingers gehad het met betrekking tot sy prediking. Jesus se gesagvolle prediking is anders as dié van 'hulle skrifgeleerdes' (Matt 7:29). Hierdie konklusie oor die gesag van Jesus verwys na die bevestiging dat Jesus nie gekom het om die wet en profete ongeldig te maak nie, maar om hulle hulle volle betekenis te laat kry (Matt 5:17). In die lig daarvan bied Jesus ses teenstellings (antitesisse) teenoor die tipe leringe van die ander skrifgeleerdes waaraan die skare gewoond was met variasies van die woorde 'Julle het gehoor dat daar ... gesê is ... Maar Ek sê vir julle ...' (Matt 5:21-48) (Viljoen 2006:155). Anders as wat die geval was met die destydse wetsgeleerdes, beroep Jesus Hom nie op die gesag van feilbare Joodse tradisies nie, maar op sy eie intrinsieke gesag (Hendriksen 1973:383). Davies en Allison (2004:726) verwys na hierdie aanspraak van Jesus as 'his intuitive awareness of the will of God in its nakedness' en 'the man himself, in daring boldness, is his own authority'. Matteus motiveer herhaaldelik in sy teks waarom Jesus met sodanige gesag mag preek; Jesus preek gesagvol, omdat Hy as Seun van God, direkte kennis van God het. Die Seun ken die Vader (vgl. Matt 11:27).

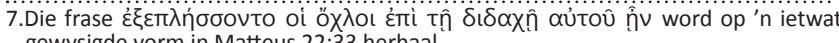
gewysigde vorm in Matteus 22:33 herhaal. 
Deurdat die gesag van Jesus wesenlik onderskei word van dié van 'hulle' skrifgeleerdes, reflekteer die woorde 'n duidelike polemiese ondertoon. Dit dui op groeiende spanning tussen Jesus en die Joodse skrifgeleerdes (Hagner 1993:194). Die skrifgeleerdes van die sinagoges se onderrig word met dié van Jesus gekontrasteer. Matteus sinspeel daarop dat die verbaasde skare tussen Jesus en 'hulle' skrifgeleerdes se interpretasie van die wet te staan kom (Luz 1989:456).

Op 'n indirekte vlak weerspieël hierdie konflik ook die spanning wat op'n latere stadium in die Matteusgemeenskap tussen die kerk en sinagoge sou ontwikkel. Die Matteusevangelie kan as transparante verhaal gelees word (Luz 2005:17). Die verhaal funksioneer op twee vlakke. Die Evangelie vertel op die boonste vlak die lewe van Jesus en sy eerste volgelinge, terwyl dit op 'n volgende vlak ook iets van die latere Matteusgemeenskap vertel (Saldarini 1991:39). Aldus kan die Sitz im Leben der alten Kirche op 'n indirekte manier in die teks herken word (White 1991:212). Uit die tweede vlak van Matteus se vertellyn blyk dat een of ander Fariseïstiese groepering meegeding het om die gesag oor en invloed op die populêre idees in die gemeenskap waarbinne die Evangelie geskryf is (Saldarini 1994:44). Matteus laat blyk dat die Fariseërs nie veronderstel is om die leiers en verteenwoordigers van die godsdienstige gemeenskap te wees nie (Repschinski 2000:63). Matteus verskerp Markus se verwysings na die Joodse leiers se rol in die teenstand en moord van Jesus. Uniek aan Matteus is sy beskrywing van die Skrifgeleerdes en Fariseërs as 'blinde leiers' en 'blinde dwase' (Matt 23:16, 17, 19, 24, 26; 15:14). Matteus identifiseer die Joodse leiers as Jesus se opponente met die skares as toeskouers van hierdie konflik. Jesus is onteenseglik elke keer die oorwinnaar in hierdie stryd. Die Jesus-volgelinge was so lojaal aan die nuwe gemeenskap gewees wat disassosiasie en spanning met hulle vorige gemeenskap tot gevolg sou hê (White 1991:216).

Die Matteus-teks openbaar verset teen die gesag van die Joodse leiers as woordvoerders van die sinagoges. Godsdienstige en politieke gesag en mag was destyds aan mekaar verwant. Die leiers van die sinagoge het die volgelinge van Jesus uit die sinagoges verban, soos verwoord in die Birkat ha minim van die Shemoneh 'Esreh wat later jare daagliks in die sinagoge gesiteer is. Die leiers van die sinagoge het hulleself as sleuteldraers beskou wat Joodse Christene uit hulle vergaderings kon weer. Hierteenoor argumenteer Matteus dat die sleutels van die koninkryk van die hemele aan die leiers van die kerk toevertrou is. Terwyl die Joodse leiers daarop aanspraak gemaak het dat hulle die sinagoge van Israel kan lei, dring Matteus daarop aan dat die Christelike voorgangers die gesag het om die kerk ooreenkomstig die onderrig van Jesus te lei. Die uitsprake van Matteus 16:19 en 18:18 dui daarop dat Petrus en die gemeenskap besondere gesag het. Die eerste uitspraak verwys na die gesag van Petrus, terwyl die tweede na die korporatiewe verantwoordelikheid van die nuwe geloofsgemeenskap verwys. Die sleutels is egter nie dié van 'n aardse organisasie nie, maar van die Koninkryk van die hemel (Viljoen 2009:667).

\section{Verbasing van die skare}

Daar was drie groepe wat die Bergrede aangehoor het; die dissipels in 'n enger sin (die twaalf), dié in 'n wyer sin (al die volgelinge van Jesus), en die skare (oi öx入oı). Luidens Matteus 7:28 was dit juis die skare wat beïndruk was deur die woorde van Jesus. Volgens Matteus was die skare die poel uit wie die kerk tot stand gekom het (Betz 1995:81). Matteus 7:28-29 verduidelik hoe verandering plaasgevind het, sodat die skare deel van die kerk kon word.

Matteus beklemtoon die impak wat Jesus se prediking op sy

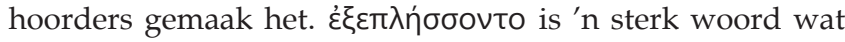
daarop dui dat hulle uiters verbaas en verwonderd was. Die imperfektum dui op 'n voortvloeiende effek. Die rede vir hulle verbasing is geleë in die gesag waarmee Jesus gepreek het (Hendriksen 1973:383).

\section{Gevolgtrekking}

Wanneer Matteus oor die gesag van Jesus handel, maak hy gebruik van 'n kontra-narratief teenoor dié van die imperiale Romeinse bondgenote en magte met spesifieke verwysings na Herodes die Grote, Herodes Antipas en Pilatus. Op'n subtiele en ironiese manier toon Matteus aan hoe hierdie persone se mag voor die skynbaar magtelose Jesus verkrummel.

Hierbenewens vertel Matteus ook van groeiende weerstand van die Joodse gemeenskap teenoor Jesus en sy dissipels. Jesus tree telkens as oorwinnaar uit die stryd. Op'n sekondêre vlak impliseer die Matteus-teks ook weerstand van die latere sinagoge wat tot die afskeiding van die kerk sou lei.

Die gesag van Jesus vorm 'n belangrike tema in die Matteusevangelie. Matteus baseer sy Christologie op die aanspraak dat Jesus as verteenwoordiger van die koninkryk van God, met unieke en onvergelykbare gesag optree. Matteus beklemtoon dat Jesus met sy eie gesag optree, gebaseer op die ware identiteit van Jesus. Daarbenewens verleen Hy ook gesag aan sy dissipels.

Die manier waarop Matteus na die gesag van Jesus verwys, sluit aan by die Romeinse begrip auctoritas waarmee die keiser in die Romeinse Ryk in teenstelling met algemene potestas opgetree het. Die gesag van die keiser is versterk deur die religieuse konnotasie wat aan hom toegedig is. In teenstelling met die eretitel van Caesar divi filius op grond waarvan die keiser besondere intellektuele en morele gesag ontvang, word Jesus as die ware Seun van God voorgestel. Soos salus rei publicae afhanklik was van hierdie posisie van die keiser, is die welsyn van die burgers van God se koninkryk van Jesus afhanklik. Soos wat die keiser sy toesprake en redes met auctoritas gevoer het, voer Jesus sy redes met superieure gesag.

Die veelseggende formule oor die gesag van Jesus waarmee Matteus die Bergrede afsluit, is besonder strategies geplaas in die ontwikkeling van die spanningslyn van die Evangelie. Jesus se gesagvolle redevoering in die Bergrede berei die 
lesers voor op die gesagvolle optrede van Jesus wat verder in die verhaal ontplooi word.

Die konklusie van die Bergrede impliseer 'n polemiese ondertoon. Jesus se gesagvolle prediking is anders as dié van 'hulle skrifgeleerdes', aangesien die skare besonder beïndruk was met sy woorde. Die skare sou die poel vorm uit wie die kerk sou ontwikkel.

Volgens Matteus het die Bergrede besondere betekenis, omdat dit op 'n uniek gesagvolle manier gelewer is. Matteus wys die leser op die allesoorheersende gesag van sy Leraar. $\mathrm{Hy}$ is nie maar een soos talle ander rabbynse leraars nie. Hy ontleen nie sy gesag van die voorvaders of van die Torah nie. Matteus skryf dat alle gesag in Jesus self geleë en onvergelykbaar is.

\section{Erkennings \\ Mededingende belange}

Die outeur verklaar dat hy geen finansiële of persoonlike verbintenis het met enige party wat hom nadelig kon beïnvloed in die skryf van hierdie artikel nie.

\section{Literatuurverwysings}

Banks, R.J., 1974, Jesus and the law in the synoptic tradition, University Press, Cambridge.

Betz, H.D., 1995, The Sermon on the Mount: A commentary on the Sermon on the Mount, including the Sermon on the Plain, Fortress Press, Minneapolis.

Bornkamm, G., 1963, 'End-expectation and church in Matthew', in G. Bornkamm, G. Barth \& H-J. Held (eds.), Tradition and interpretation in Matthew, pp. 26-51, Westminster, Philadelphia.

Carter, W., 2000, Matthew and the margins: A socio-political and religious reading, Journal for the Study of the New Testament suppl. ser. 204, Sheffield Academic Press, Sheffield.

Carter, W., 2001, Matthew and empire: Initial explorations, Harrisburg, Trinity Press International.

Cousland, J.R.C., 2002, The crowds in the Gospel of Matthew, Brill, Leiden/Boston/ Köln.

Davies, W.D., 1963, The setting of the Sermon on the Mount, University Press, Cambridge.

Davies, W.D. \& Allison, D.C., 2004, A critical and exegetical commentary on the Gospel according to Saint Matthew, Volume 1 (Matthew 1-7), T \& T Clark, London/New York. (International Critical Commentary.)

Dunn, D.G., 1980, Christology in the making, Westminster, London.

Dunn, D.G., 1991, The parting of the ways between Christianity and Judaism and their significance for thecharacter of Christianity, Trinity Press International, Philadelphia.
France, R.T., 1989, Matthew: Evangelist and teacher, Intervarsity Press, Illinois.

France, R.T., 2007, The Gospel of Matthew, Eerdmans, Michigan/Cambridge.

France, R.T., 2008a, 'Matthew and Jerusalem', in D.M. Gurtner \& J. Nolland (eds.), Built upon the Rock: Studies in the Gospel of Matthew, pp. 108-127, Eerdmans, Grand Rapids/Cambridge.

France, R.T., 2008b, Matthew, vol. 1, Inter-varsity Press, Nottingham. (Tyndale New Testament Commentaries.)

Galinsky, K., 1996, Augustan culture: An interpretive introduction, University Press, Princeton.

Hagner, D.A., 1993, Matthew 1-13, vol. 33A, Word Books, Dallas. (Word Biblical Commentary.)

Hendriksen, W., 1973, The Gospel of Matthew, Banner of Truth Trust, Edinburgh. (New Testament Commentary.)

Hummel, R., 1966, Die Auseinandersetzung zwischen Kirche und Judentum im Matthäusevangelium, Kaisar, München.

Keener, G.S., 1999, A commentary on the Gospel of Matthew, Eerdmans, Michigan.

Kingsbury J.D., 1976, 'The title "Son of David" in Matthew's Gospel', Journal for Biblical Literature 95, 591-602. http://dx.doi.org/10.2307/3265574

Luz, U., 1989, Matthew 1-7: A commentary, T \& T Clark, Edinburgh.

Luz, U., 2001, Matthew 8-20: A commentary, Fortress, Minneapolis.

Luz, U., 2005, Studies in Matthew, Eerdmans, Grand Rapids.

Overman, J.A., 1990, Matthew's gospel and formative Judaism: The social world of the Matthean community, Fortress, Minneapolis.

Patte, D., 1987, The Gospel according to Matthew: A structural commentary on Matthew's faith, Fortress, Philadelphia.

Radford Reuther, R., 1974, Faith and fratricide: The theological roots of anti-Semitism, Seabury, New York.

Repschinski, B., 2000, The controversy stories in the Gospel of Matthew: Their redaction, form and relevance for the relationship between the Matthean community and formative Judaism, Vandenhoeck \& Ruprecht, Göttingen.

Saldarini, A.J., 1991, 'The Gospel of Matthew and Jewish-Christian conflict', in D.L. Balch (ed.), Social history of the Matthean community: Cross-disciplinary approaches, pp. 38-61, Fortress, Minneapolis.

Saldarini, A.J., 1994, Matthew's Christian-Jewish community, University of Chicago, Chicago.

Senior, D., 1998, Matthew, Abingdon, Nashville. (Abingdon New Testament commentaries.)

Stanton, G.N., 1992, 'Matthew's Christology and the parting of the ways', in J.D.G. Dunn (ed.), The parting of the ways AD 70 to 135: The second Durham-Tübingen research Symposium on Earliest Christianity and Judaism, Durham, September 1989, pp. 99-116, Tübingen, Mohr-Siebeck. (WUNT, 66.)

Van Bruggen, J., 1990, Matteüs: Het evangelie voor Israël, Kok, Kampen. (Commentaar op het Nieuwe Testament, derde serie.)

Viljoen, FP., 2006, 'Jesus' teaching on the Torah in the Sermon on the Mount', Neotestamentica 40(1), 135-156.

Viljoen, F.P., 2007, 'Matthew, the church and anti-Semitism', Verbum et Ecclesia 28(2), 698-718.

Viljoen, F.P., 2009, 'Die kerk en geregtigheid in die Matteus-evangelie', In die Skriflig 43(3), 649-667.

Weaver, D.J., 1996, 'Power and powerlessness: Matthew's use of irony in the portrayal of political leaders', in D.R. Bauer \& M.A. Powell (eds.), Treasures new and old: Contributions to Matthean studies, pp. 179-196, Scholars Press, Atlanta.

Wengst, K., 1987, Pax Romana and the peace of Jesus Christ, Fortress, Philadelphia.

White, L.M., 1991, 'Crisis management and boundary maintenance: The social location of the Matthean community', in D.L. Balch (ed.), Social history of the Matthean community: Cross-disciplinary approaches, pp. 210-225, Fortress, Minneapolis. 